Techniques \& Culture

Revue semestrielle d'anthropologie des techniques

19 | 1993

Itinéraires, escales

\title{
Le byssus ou laine d'or
}

\section{Aurore Sagot-Ortéga}

\section{OpenEdition}

Journals

Édition électronique

URL : https://journals.openedition.org/tc/674

DOI : $10.4000 /$ tc. 674

ISSN : 1952-420X

Éditeur

Éditions de l'EHESS

Édition imprimée

Date de publication : 1 mai 1993

ISSN : 0248-6016

\section{Référence électronique}

Aurore Sagot-Ortéga, « Le byssus ou laine d'or », Techniques \& Culture [En ligne], 19 | 1993, mis en ligne le 10 janvier 2006, consulté le 29 septembre 2022. URL : http://journals.openedition.org/tc/674 ; DOI : https://doi.org/10.4000/tc.674

Ce document a été généré automatiquement le 29 septembre 2022

Tous droits réservés 


\section{Le byssus ou laine d'or}

Aurore Sagot-Ortéga 